\title{
AMBIENT SONG KARYA KELOMPOK MUSIK DINDING KOTA KAJIAN TENTANG PROSES PEMBUATAN DAN PEMANFAATAN SEBAGAI MEDIA MEDITASI
}

\author{
Ciptaning Indra Wangsa ${ }^{1}$, Bagus Susetyo ${ }^{2}$ \\ Pendidikan Seni Musik, Universitas Negeri Semarang \\ E-mail: indraskatepunk@ rocketmail.com \\ E-mail: bagussusetyo45@gmail.com
}

\begin{abstract}
ABSTRAK
Meditasi merupakan langkah mengenal diri untuk kebaikan dan keseimbangan hidup. Meditasi dapat dibantu dengan menggunakan musik yang disebut musik ambient. Di kota Semarang terdapat grup musik yang memainkan musik ambient bernama Dinding Kota. Permasalahan yang diteliti adalah bagaimana cara membuat ambient dan bagaimana memanfaatkan ambient sebagai media meditasi. Tujuan penelitian ini untuk mendeskripsikan bagaimana cara membuat ambient yang bisa digunakan sebagai media meditasi, yang memiliki manfaat sebagai informasi kepada masyarakat luas agar mengetahui fungsi musik ambient. Penelitian ini menggunakan metode deskriptif kualitatif dengan pengambilan data berupa wawancara, observasi, dan dokumentasi. Dalam membuat ambient pada grup band Dinding Kota memiliki sembilan langkah berupa perenungan, memilih latar belakang, menentukan tema dan konsep, memilih instrument, memilih efek, mengatur efek, mengatur amplifier, dan membuat ambientpart dan ambientnotes. Penggunaan Ambient sebagai media meditasi menggunakan headphone atau headset dengan posisi tubuh duduk atau berbaring dan fokus mendengarkan musik ambient. Ambient merupakan suatu jenis musik yang menghasilkan dimensi lain didalamnya yang dapat mempengaruhi pikiran dan sugesti seseorang dengan suara dengungan yang dapat digunakan sebagai media meditasi.
\end{abstract}

Kata kunci: Ambient song, Media, Meditasi, dan kelompok musik Dinding Kota.

\section{PENDAHULUAN}

Pada dasarnya manusia sebenarnya memiliki sifat dasar yang sudah tertanam pada tubuh seperti sifat welas asih, rasa penyayang, empati yang tinggi, saling gotong royong, rasa social yang tinggi, dan lain-lain. Diakarenakan semakin bekembangnya zaman dan tekhnologi membuat manusia sekarang menjadi lebih individualistis dan semakin tidak memperdulikan hal-hal keadaan sekitar lingkungan. Memunculkan kembali sifat-sifat dasar manusia seperti sifat welas asih, penyayang, empati, gotong royong dan jiwa social yang tinggi bisa melalui cara mendekatkan diri dengan Tuhan dengan cara beribadah sesuai kepercayaan masing-masing dan juga dengan meditasi.

Menurut (Suhirman, 2007: 49) meditasi adalah bagian latihan mengenal diri yang berguna untuk menenangkan pikiran, membuka pikiran, mencerahkan pikiran, meningkatkan kesehatan, kesadaran, kebijaksanaan,kesadaran,mengembang kankebijaksanaan, membuka pintu inspirasi, dan memicu kreativitas yang 
sempurna. Meditasi akan membawa kita ke alam bawah sadar manusia untuk menemui diri sejati tubuh dan menuju ke sumber hidup guna memberi arahan positif untuk melakukan tindak tanduk kehidupan manusia didunia. Meditasi biasanya dilakukan diluar ruangan atau outdoor berlatang belakang hutan, rawa-rawa, pantai,dan lain-lain guna mendapatkan nuansa suara-saura alam yang menenangkan, tetapi pada zaman modern ini meditasi bisa dilakukan didalam sebuah ruangan seperti didalam kamar dengan bantuan musik yang disebut dengan musik ambient.

Ambient adalah sesuatu bebunyian pembangkit suasana dasar, yang merupakan bebunyian panjang dengan frekuensi yang diatur sedemikian rupa, dengan mengacu pada suatu suara atau musik yang bisa dihasilkan oleh satu sumber suara atau lebih yang bersifat nuansa dimensi lain atau instrumental (Hanif Nugraha, 2010). Di Kota Semarang terdapat grup musik yang memainkan musikmusik ambient yang bernama grup band Dinding Kota. Keunikan dari musik ambient Dinding Kota terletak pada proses pembuatan yang unik dan alat yang digunakan juga relative rumit. Oleh sebab itu, peneliti tertarik untuk meneliti bagaimanakah proses pembuatan musik ambient dan bagaimana cara pemanfaatan musik ambient sebagai media meditasi pada grup musik Dinding Kota. Tujuan dari penelitian ini untuk menjelaskan dan mendeskripsikan bagaimana cara membuat musik ambient dan bagaimana cara pemnafaatanya sebagai media meditasi, yang bermanfaat sebagai pengetahuan lembaga pendidikan dan masyarakat umum agar lebih mengetahui manfaat dari musik ambient.

\section{METODE PENELITIAN}

Penelitian ini meneliti tentang ambient song karya kelompok musik Dinding Kota kajian tentang proses pembuatan ambient dan pemanfaatan sebagai media meditasi dengan menggunakan metode pendekatan studi kasus, yaitu mencari data tentang sebuah hasil kegiatan sebuah kelompok yang hasil datanya bersifat natural. Metode penelitian ini menggunakan metode penelitian deskriptif kualitatif dengan mendeskripsikan seluruh isi skripsi secara detail, jelas, dan menyeluruh sesuai data yang telah didapatkan tentang proses pembuatan ambient dan pemanfaatan musik ambient sebagai media meditasi. Pengambilan data dilakukan dengan tiga metode dengan cara observasi, wawancara, dan dokumentasi.

Observasi pada penelitian ini bertujuan untuk memperoleh data tentang proses pembuatan ambient pada grup musik Dinding Kota guna pelaksanaan evaluasi. Lalu pengambilan data berupa wawancara terhadap pendiri atau manager grup band Dinding Kota, personil Dinding Kota, dan tiga orang masyarakat umum untuk uji sampel yang bertujuan untuk memperkuat data. Tekhnik pengambilan data yang terakhir berupa dokumentasi yang bertujuan untuk mendapatkan data-data gambar proses pembuatan ambient dan audio lagulagu karya Dinding Kota yang digunakan sebagai media meditasi. Tekhnik analisi data dilakukan dengan menggunakan tekhnik pengumpulan data, reduksi data, dan penarikan kesimpulan atau verifikasi. Dalam 
studi pustaka, peneliti menggunakan penelitian terdahulu dari buku The Power Of Sound karya Diddi Agephe tahun 2010, dan penelitian ini menggunakan tekhnik keabsahan data berupa tekhnik confirmalbility yaitu persamaan pendapat antara sampel dan narasumber yang diwawancarai, dengan hasil teori yang telah diutarakan oleh para ahli sehingga menimbulkan fakta yang sah.

\section{HASIL PENELITIAN DAN PEMBAHASAN}

Musik ambient merupakan suatu musik yang dapat menghasilkan suatu dimensi alam lain yang dirasakan pendengarnya untuk mensugesti pendengar agar masuk kedalam alam bawah sadar atau pikiran meditative. Musik ambient merupakan sebuah musik instrumental dengan dengungan-dengungan yang bergema. Proses penelitian ini memfokuskan kepada kajian tentang proses pembuatan ambient song dan pemanfaatan musik ambient sebagai media meditasi. Dalam hal ini observasi dilakukan di basecamp grup band Dinding Kota yang bertempat di Jalan Taman Kukilo Mukti Utara 2 No. 3 Kecamatan Pedurungan, Kelurahan Pedurungan Kidul, Semarang sebanyak satu kali observasi yang sekaligus dilakukan dengan wawancara, dan dokumentasi sehingga mendapatkan hasil data yang sesuai dengan apa yang diobservasi dengan penjelasan yang diutarakan dari narasumber. Berdasarkan hasil wawancara pada tanggal 23 Juni 2016 bahwa pembuatan ambient pada kelompok musik Dinding Kota dilakukan dengan sembilan tahap, tahap tersebut sudah menjadi sebuah patokan pada kelompok musik Dinding Kota

\section{Proses Pembuatan Ambient}

Ambient Song adalah musik yang bernuansa gema atau dengungan dengan melodi yang menyerupai lirik atau melodi berlagu, tetapi tidak dimainkan dengan vocal melainkan dengan alat musik instrument (Brian Eno, 1988). Dalam pembuatan ambient pada kelompok musik Dinding Kota terdapat sembilan langkah proses pembuatanya yaitu perenungan, membuat latar belakang, menentukan tema dan konsep, memilih instrument, memilih dan mengatur efek, mengatur amplifier dan membuat ambient notes dan ambient part. Dalam langkah pertama dalam membuat ambient pada kelompok musik Dinding Kota adalah perenungan. Para personil Dinding Kota biasanya juga melakukan sebuah meditasi atau perenungan sebelum membuat karya yang berfungsi untuk mengosongkan pikiran agar pikiran bisa dalam tahap jernih dan positif. Sesuai pernyataan (Suhirman, 2007 : 49) meditasi dapat membuka semua pikiran untuk menuju kegiatan yang lebih baik. Hal ini sesuai dengan hasil wawancara dari narasumber pendiri sekaligus manager kelompok musik Dinding Kota berikut :

"Sebelum memulai membuat lagu, biasanya kita (semua personil Dinding Kota) melakukan sebuah perenungan atau meditasi secara individu, agar pikiran kami terbuka dan ide-ide yang kami pikirkan bisa dituangkan dalam sebuah musik, dan juga agar tidak sama dengan musikmusik dari referensi kita" (wawancara 23 Juni 2014). Dalam perenungan pada kelompok musik Dinding Kota biasanya sebagian individu bermeditasi selama satu hari didalam sebuah kamar ataupun dengan berpergian diluar ruangan seperti 
dipantai dan tanpa mendengarkan lagu sama sekali, sehingga lagu yang diciptakan seperti segar hasil asli dari pemikiran. Biasanya jika seseorang ingin membuat karya tetapi melihat hasil karya orang lain sebelumnya maka karya orang lainpun juga akan terserap oleh pikiran dan mengakibatkan karya yang dibuat hampir sama meskipun tidak ada unsure kesengajaan, tetapi akan mendapatkan citra dan pandangan buruk dari beberapa masyarakat yang mengetahui beberapa referensireferensi musik ambient. Hal ini sesuai dengan wawancara sebagai berikut.

"Biasanya kita meninggalkan musik dan tidak mendengarkan musik selama berhari-hari. Didalam perenungan kita akan bisa menuangkan pikiran asli kita didalam musik" (wawancara tanggal 23 Juni 2016). Setelah memasuki proses perenungan, para personil Dinding Kota biasanya akan bermusyawarah tentang latar belakang, tema dan konsep apa yang dimasukan dalam lagu tersebut agar jelas dalam dasar lagu tersebut mengandung pesan dan cerita didalamnya. Setelah membuat latar belakang, tema dan konsep maka pars personil Dinding Kota akan menyiapkan berbagai macam alat-alat musik seperti gitar, efek, bass, drum, dan aksesoris-aksesoris lainya. Hal ini sesuai dengan hasil wawancara sebagai berikut.

"Kami menyiapkan beberapa banyak macam peralatan untuk membuat musik ambient, karena memang musik ambient merupakan musik yang memiliki berbagai unsur macam suara, sehingga persiapan alatalat yang mengandung berbagai macam suara juga kami persiapkan" (wawancara tanggal 23 Juni 2014).
Dalam membuat musik ambient, peralatan yang berkualitas dan memadai akan mempengaruhi suara yang dihasilkan. Karena peralatan yang memadai akan menghasilkan suara maksimal yang diharapkan, seperti adanya sustain yang panjang, tingkat kejelasan suara atau tone yang jelas, dan tingkat playbility alat yang nyaman saaat dimainkan. Menurut Bayyin Nur dalam (Audio Pro, 2011: 22) alat yang berkualitas dapat menghasilkan sustain yang panjang sangat perlu digunakan. Hal ini diperjelas dengan pendapat ahli lainya, pemilihan alat yang berkualitas merupakan salah satu alat pendukung dan penunjang penampilan musisi saat diatas panggung (Yulia, 2009: 33). Hal ini sesuai dengan hasil wawancara berikut :

"Dalam musik ambient, kami sangat memerlukan alat-alat yang minimal mempunyai standart kualitas yang baik, agar hasil suara ang dihasilkan dalam membuat ambient juga maksimal" (wawancara tanggal 23 Juni 2016).

Arah pada suatu musik yaitu mengarah kepada bunyi. Menurut (Slamet, 2012: 5) bunyi adalah gelombang yang menjadi dalam bagian kosmos (alam semesta). Musik dan bunyi bedanya hanya terletak pada kemampuan kita untuk mencernanya sebagai musik atau bukan, tinggal masalah kepekaaan atau budaya kita. Menurut Michael Gunadi dalam (Audio Pro, 2009: 35) manusia mempersepsikan bunyi sebagaimana hal-hal lain dalam kehidupan ini. Persepsi terhadap bunyi seberapapun akan menentukan bagi citra penyajian bunyi. Bunyi dihasilkan dari beberapa alat musik yang bernada atau melodis seperti gitar, biola, keyboard, 
saxophone maupun alat yang tidak bernada atau ritmis seperti drum, cajon, dan alat-alat perkusi lainya. Bunyi tidak harus dihasilkan menggunakan alat musik melodis dan ritmis, adapun juga bunyi dihasilkan dari suara burung berkicau, pohon tumbang, suara ledakan bom, dan lainlain tergantung bagaimana kita mempersepsikan bunyi itu sebagai musik atau bukan. Dalam membuat ambient, suara-suara yang dihasilkan melalui seperangkat alat elektronik yang biasa disebut efek. Menurut (Jimi, 2012: 67) efek merupakan bagian dari rangkaian alat-alat elektronik yang digunakan pada alat musik elektrik seperti gitar elektrik ataupun bass elektrik untuk menghasilkan warna suara yang berkarakter dan khas. Efek mempunyai dua jenis tipe, yaitu efek yang bertipe high gain dan efek yang bertipe modulation. Hal ini diperjelas dengan hasil wawancara berikut :

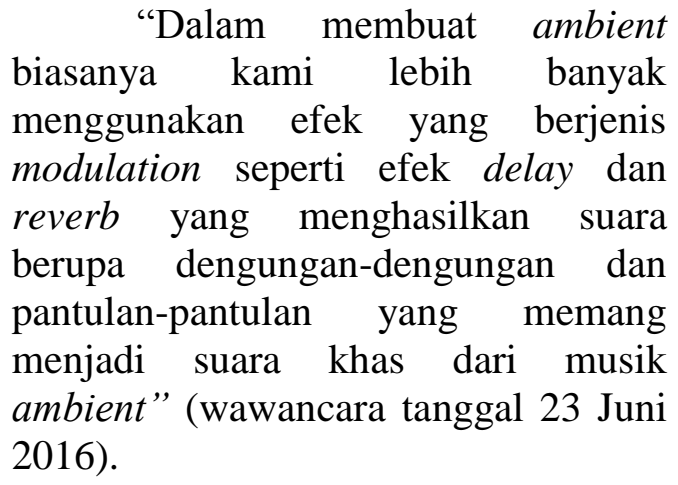

Ciri khas dari musik ambient tersebut terletak pada dengungandengungan suara yang dihasilkan melalui efek reverb dan delay yang menghasilkan sugesti dimensi lain kepada pendengar musik ambient. Hal ini juga diperjelas dari beberapa ahli, menurut (diDDI AGePhe, 2010: 87) menyatakan bahwa musik bergema dan berfrekuensi rendah dibawah $20 \mathrm{Khz}$ akan membantu seseorang memasuki tahap tenang atau frekuensi alfa.

\section{Pemanfaatan Ambient Song Sebagai Media Meditasi}

Pada zaman sekarang terutama dikota-kota besar yang sudah ikut arus globalisasi musik kini beralih fungsi. Apabila di desa-desa ataupun disukusuku pedalaman, musik masih digunakan sebagai pemujaan atau pengusir terhadap roh-roh halus, sembahyang, pemanggil hujan, dan lain-lain. Berbeda jika diperkotaan biasanya musik digunakan hanya sebagai hiburan. Salah satu hal yang sama dalam fungsi musik didaerah yang masih kental dengan budayanya dan dengan fungsi musik didaerah perkotaan yaitu musik berfungsi sebagai media penyembuhan kejiwaan. Di perkotaan yang padat dan bising membuat manusia rentan stress dan mengalami emosi yang tidak stabil, sehingga perlu obat penenang secara alamiah yang disebut musik. Menurut (Irmasnyah, 2015: 129 ) musik menghasilkan getaran. Getaran adalah elemen dasar dari energi. Getaran yang sesuai dapat membantu proses pembersihan tubuh, penembuhan kejiwaan, pembersihan cakra, dan pengaktifan cakra bagi siapapun yang mendengarkan musik secara fokus. Pada dasarnya semua musik dapat membangun sebuah emosi dan perbaikan jiwa, tetapi lain halnya pada musik instrumental yang memiliki nilai getaran lebih dan dengan tempo yang lambat akan merangsang otak untuk bekerja lebih rileks. Hal ini sesuai dengan wawancara sebagai berikut :

"Musik-musik bernuansa instrumental dengan tempo yang lambat dan irama-irama panjang didalamnya dapat merangsang tubuh 
untuk rileks. Seperti halnya dalam musik classic yang bersifat instrumental dari karya-karya J.S Bach atau Mozart yang dapat difungsikan untuk terapi kecerdasan bayi" (wawancara tanggal 23 Juni 2016).

Dalam bermeditasi menggunakan musik tidak bisa lepas dari beberapa perangkat media yang digunakan, seperti headset atau headphone, alat pemutar lagu atau juga bisa menggunakan handphone. Menurut (Sadiman, 1993: 6) media adalah perantara atau pengantar pesan dari pengirim ke penerima pesan. Kata media dalam pengertian sempit yang berarti sasaran. Hal ini diperjelas dengan hasil wawancara berikut :

"Mendengarkan musik ambient menggunakan media headphone lebih terasa suasananya daripada mendengarkan secara langsung" (wawancara 24 Juni 2016).

Bermeditasi menggunakan musik tidak terbatasi oleh usia, derajat seseorang, atau tingkatan seseorang lainya. Hal ini diperjelas oleh ahli yang berpendapat bahwa musik adalah bahasa alam semesta, suatu bahasa yang tidak pernah memandang latar belakang si pendengar, baik agama maupun kepercayaanya (Margaret Widiyanti dalam Diddi Agephe, 2010: XII). Musik meditasi disini berfungsi untuk merileksasikan otak agar berada pada jalur frekuensi alfa atau frekuensi meditative, menenangkan hati dan pikiran. Dalam bermediatasi tidak boleh memikirkan hal-hal lainya selain fokus pada pikiran dan mengatur pola nafas secara baik, sehingga perjalanan menuju alam bawah sadar bisa tercapai dengan baik. Biasanya orang-orang yang pertama kali melakukan meditasi akan sangat kesusahan untuk berkonsentrasi. Hal ini sependapat juga oleh ahli. Menurut (Adjie, 2015: 3) lompatan pikiran itu disebut monkey mind, bisa terjadi dikarenakan pikiran yang tidak bisa focus. Hal ini juga diperjelas dalam hasil wawancara berikut :

"Pada awalnya sulit untuk berkonsentrasi karena ada pikiran lain yang masuk kedalam pikiran saya sehingga saya tidak bisa merasa tenang" (wawancara 24 Juni 2016).

Penggunaan musik untuk bermeditasi inilah yang digunakan untuk memfokuskan otak karena dimensi lain yang dihasilkan dari musik tersebut. Tetapi juga perlu diingat bahwa factor suhu dan metabolism tubuh juga akan mempengaruhi berhasil atau tidaknya seseorang untuk fokus pada pikiranya dalam bermeditasi. Meditasi menggunakan musik lebih baik jika dilakukan pada sore ataupun saat sepertiga malam.

Saat seseorang sudah sering bermeditasi maka akan muncul sifat spiritual pada diri dan keseharian. Spiritual adalah suatu kegiatan yang membahas hal-hal yang berhubungan dengan kejiwaan, rohani, batin, mental, cakra dan moral (d OM ik d HEO, 2015: 122). Spiritual merupakan sifat-sifat yang tidak bisa terlepas dari hal kerohanian dan kejiwaan. Biasanya sifat spiritual pada manusia terlihat bagaimana tindak tanduknya dalam kehidupan sehari-hari, tutur bahasa yang baik, penyayang, pemaaf, pemberi contoh yang baik, dan lainlain. Sifat spiritual akan membawa manusia itu sendiri kedalam posisi yang selalu tepat dan bijaksana.

Selain memunculkan sifat-sifat spiritual pada orang yang bermeditasi, meditasi juga akan mengaktifkan seluruh elemen jagad raya yang ada 
ditubuh. Elemen tersebut disebut dengan cakra. Menurut Kemper dan Denhaueur 2005 dalam (Tetti, 2015: 181) musik membuka cakra, memperlambat dan menyeimbangkan gelombang otak. Cakra dalam tubuh manusia terbagi menjadi tujuh bagian, empat merupakan elemen yang berada dibumi seperti elemen api, air, tanah, dan udara, dan tiga elemen kehidupan yaitu elemen ketuhanan, perasaan, dan komunikasi.

Apabila ketujuh cakra yang diaktifkan dalam tubuh manusia maka akan berdampak baik dan akan berpengaruh kepada orang lain. Pada cakra pertama yaitu cakra dasar yang akan menjadikan manusia tetap selalu rendah hati, karena cakra ini merupakan elemen cakra tanah yang memiliki simbolik dasar sikap. Yang kedua ada cakra sex yang memiliki simbolik agar kita tidak lupa untuk selalu patuh terhadap oang yang lebih tua. Yang ketiga ada cakra perut, merupakan simbolik dari elemen api yang merupakan pusat kekuatan.Yang keempat merupakan cakra jantung yang berfungsi sebagai penumbuh perasaan baik terhadap alam dan sekitar. Yang kelima adalah cakra tenggorokan yang mempunyai simbolik agar bertutur kata yang baik. Yang keenam adalah cakra mata ketiga yang memiliki simbolik untuk melihat dan membuat masa depan lebih baik. Dan yang terkahir merupakan cakra mahkota agar manusia selalu ingat bahwa ada yang lebih tinggi dari segalanya.

\section{KESIMPULAN DAN SARAN}

Berdasarkan hasil penelitian mengemukakan suatu kesimpulan sebagai berikut.

Dari proses pembuatan ambient yang begitu panjang yang meliputi sembilan tahap yaitu perenungan, memilih latar belakang, memilih tema dan konsep, memilih instrument atau alat musik berupa gitar, bass, dan drum, memilih efek yang berkarakter highgain dan modulation, mengatur efek, mengatur amplifier dan membuat ambient part dan ambient notes yang digabungkan sehingga membentuk ambient song. Dari segi pemanfaatan ambient sebagai media meditasi dan penyembuhan penyakit jiwa dapat ditarik kesimpulan bahwa musik ambient dapat menghasilkan getaran dan gelombang yang dapat merangsang otak untuk rileks, rasa yang disalurkan keseluruh tubuh untuk melakukan meditasi untuk memberi manfaat posistif dalam suatu kehidupan manusia sehari-hari kepada diri sendiri dan untuk keseimbangan alam semesta beserta isinya. Berdasarkan penelitian dapat dikemukakan saran sebagai berikut :

Saran dari penelitian ini adalah agar proses pembuatan musik ambient seperti proses perenungan, memilih latar belakang, memilih tema dan konsep, memilih instrument, memilih efek, mengatur efek, dan mengatur amplifier agar bisa lebih disederhanakan lagi karena terlalu banyak cara, seperti dihilankan proses perenungan dikarenakan tidak semua masyarakat bisa melakukan perenungan untuk membuat suatu karya. Selain itu cara lainya tetap dipertahankan karena memuat beberapa aspek dasar pembuatan ambient. Saran dari segi pemanfaatan ambient sebagai media meditasi agar lebih banyak panduan-panduan bermeditasi berupa buku atau artikel yang membantu orang yang akan bermeditasi menggunakan musik sebagai medianya agar lebih mengetahui dan paham bagaimana 
cara bermeditasi menggunakan musik ambient.

\section{REFERENCES}

Agephe, Diddi. 2010. The Power Of

Sound. Jakarta : PT. Gramedia Pustaka

Utama Jakarta.

D Heo, d OMik. 2015. Desain Jiwa. Jakarta. PT. Elex Media Komputindo Jakarta.

Effendi, Irmansyah. 2015. Kundalini. Jakarta. PT. Gramedia Pustaka Utama Jakarta.

Jimi, 2012. Belajar Tekhnik Gitar Ala Dewa Gitar. Jakarta. Pustaka Safy Yogyakarta.

Rendra, Yulia. 2009. Belajar Tekhnik Fenomenal Dewa Gitar Steve Vai. Jakarta. Pustaka Safy Yogyakarta.

Sadiman, 1993. Media Pendidikan. Jakarta. PT. Raja Grafindo Persada Jakarta.

Silarus, Adjie. 2015. Sadar Penuh Hadir Utuh. Jakarta. Transmedia Pustaka Jakarta.

Sjukur, Slamet Abdul. 2012 Virus Setan. Yogyakarta : Art Music Today Yogyakarta.
Solehati, Teti. 2015. Konsep dan Aplikasi Relaksasi dalam Keperawatan Maternitas. Jakarta. PT. Refika Aditama Jakarta.

Suhirman. 2007. Manfaat Aikido Bagi Pembinaan Spiritual Leadership. Jakarta. PT. Gramedia Pustaka Utama Jakarta.

Suharto. (1997). Musik dan Bahasa.Media 20(4), 286-393

Pro, Audio. 2009. Persepsi Terhadap Bunyi. Jakarta. Audio Pro Jakarta.

Pro, Audio. 2011. Memilih Pickup Gitar Elektrik. Jakarta. Audio Pro Jakarta.

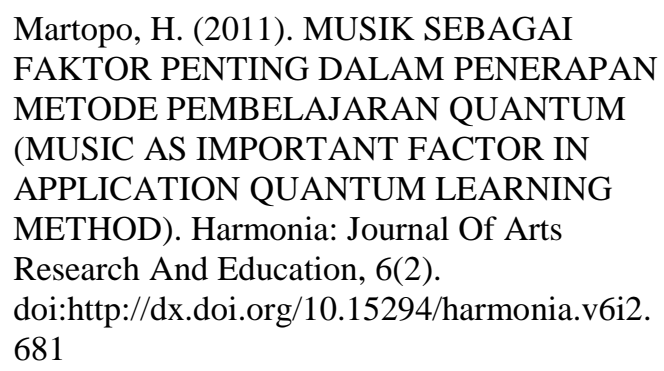


